\title{
Technology is indispensable. This is true both for non-literary and for literary translators increasingly
}

La tecnología es indispensable. Esta afirmación es válida cada vez más para los traductores, tanto literarios como no literarios

\section{Tomáš SvoBoda}

Institute of Translation Studies, Universidad Carolina

Tomas.Svoboda@ff.cuni.cz

\section{INTRODUCCIÓN}

From explaining his passion for matters related to translation, to topics such as localisation, news dissemination or translation skills, to the outlook for the translation profession. Tomáš Svoboda of Charles University, Prague, speaks about broader contexts of translating today.

Keywords: tools and technologies in translation; translation quality. 


\section{ENTREVISTA}

Fecha: 3/6/2020

Don de Lenguas: Tomaš Svoboda, profesor de traducción en la Universidad Carolina de Praga en la República Checa. Sus especialidades son los aspectos de calidad en la traducción, la traducción institucional y las aplicaciones de la tecnología en la traducción, junto con la localización. Por ser un invitado tan internacional el de hoy, vamos a realizar la entrevista en inglés. Good morning, professor. How are you?

Tomaš Svoboda: Good morning! Thank you very much. I am very happy to be in Salamanca, such a beautiful city.

DDL: The same for us, we are very thankful for your being here today. To break the ice, firstly I would like to ask you: when did you find out you wanted to be a translator and what prompted you to start your studies in the field of translation?

TS: Very interesting question to start with. I got interested in languages because, for me, languages meant freedom. I grew up in the time of the communist regime in Czechoslovakia before 1989 and, if you wanted to get uncensored information, you had to look for information outside your country, outside the official media. So that is how I got interested in languages. I followed news in German because I grew up near the Austrian border and, as you know, in Austria they speak German. That was my first contact with foreign languages. In high school, I added English and obviously Russian was the foreign language that we had to study. So, at high school I already had three foreign languages. And then I thought what to do in my professional career, so I thought "yeah I like languages and l'd like to do something practical with languages». So that was my path towards translation. Also, I would like to mention my grandmother who was a translator and interpreter, and I was able to see the very interesting things that she did, she had a very interesting job. This inspired me as well.

DDL: OK, that is a very interesting, very personal experience. We are very grateful to hear it. I like what you said about society sort of making you have to learn languages and the fact that you take advantage of that opportunity, I think it's fantastic. Well, let's get into some more concrete questions. In the seminar, you will be addressing the topic of the interrelation between technology, translation, and communication, which is a topic very debated nowadays. In our modern society, can translation as a professional activity and communication in general be conceived without technology?

TS: Hardly so. You know, technology is ubiquitous, l'd say. It is everywhere and very often we don't even realize it is technology means that we are using. Technology is found in transportation, media, entertainment communication, obviously, etc. We just are dependent on technology nowadays. The same goes for translation. Interestingly,

Tomáš SVOBODA

Technology is indispensable. This is true both for non-literary and for literary translators increasingly
CLINA

vol. 7-1, June 2021, 25-31

elSSN: 2444-1961

Ediciones Universidad de Salamanca - CC BY-NC-ND 
people who are familiar with translation studies and the use of technology in translation today are familiar with the term "computer assisted translation", which you understand as a specific tool, as a specific software helping professional translators. But if you look at the concept more broadly, you will see that there is no such thing as translation without the assistance of computers. You simply don't type in a typewriter today, so even if you don't use the specific CAT tool, as it's called, you use the computers. Translation is assisted by computers today in any aspect. Even literary translation where we tend to think less of technology influences, even literary translation is influenced by technology.

DDL: So, we can see this computer assisted translation you've talked about has an irreplaceable place in the field. We students are usually told about this. I mean, our professors tell us about these systems that are irreplaceable. Does technology have any influence or impact on how news is disseminated? Nowadays we are told many times that we live in a global society and there is fake news out there. I mean, does it have any real impact on how news gets to us?

TS: Absolutely. Communication at large is based on the Internet. We tend to consume news more from our tablets and hand-held devices in general less from printed media. Since communication is a dynamic field and Internet based, it can also be very easily influenced. Interestingly, you see people communicating via technology even when they sit next to each other. Communication is technology and Internet based, and the same goes for news. In these respects, the new sites, or social networks that we consume news through tend to motivate us to stay with this channel for as long as possible. It is not the news' reliability and relevance that is at stake, it is how interesting it is to you. And the network tries to motivate you to stay with it. That is why we become so caught up in news bubbles. And this can become a bit of a challenge for democratic institutions because news tends to lack objectivity nowadays.

DDL: So, being such a big one, the impact of technology in communication, do you think that this «technologization», as we might call it, might mean that at some point we will stop reading books and thus translators' skills as we can see them generally will be of no value?

TS: I would distinguish a few things here. Technologization means simply that we increasingly use technology, perhaps more than we need to, more than we should, too. Because it is so convenient and we're becoming lazy, on the one hand. On the other hand, this does not mean that people will stop reading books. What I'm seeing, I think it's true for the Czech society and I hope it's true for other societies in Europe as well, people have not stopped reading books. When I travel to work every morning on the subway in Prague, you see very many people reading a book on the subway, so that's great news. Also, the statistics tell us that books production has not dropped significantly. This is not a development that we should be afraid of. We use technology, we

Tomáš SVOBODA Technology is indispensable. This is true both for non-literary and for literary translators increasingly
CLINA

vol. 7-1, June 2021, 25-31

elSSN: 2444-1961

Ediciones Universidad de Salamanca - CC BY-NC-ND 
are dependent on it, on the one hand, but on the other hand, books are here to stay, I am convinced. At the same time, technology opens new channels for the way that we consume information or read stories. Apart from paper printed books, you also have avoid this split on two lines, put on one line only. What does this mean for translation? People will always be interested in stories; people will always be interested in what is beyond their regular, everyday experience. They just want to have their dreams; they want to learn about other people's fate and history. So, both printed books and e-books are here to stay. Literature is here to stay. This is good news for translators, because still also communicating across borders, communicating across linguistic and cultural borders will be a necessity in the future. Translators are on the safe side.

DDL: Quite an encouraging piece of news or statement for translation students. We get told or warned by many people quite a few times that in the future we're not going to have jobs, that computers are going to do all the things we do. But you've actually mentioned an interesting feature of translation which is on communicating stories across borders. Regarding these stories, I think it is widely believed that the stories that the youth consumed nowadays are video games. The way that video games have entered the consumer market is a new one. I would like to know your thoughts on the video games industry and how do you see it as a possible market for translators?

TS: I would start with a personal experience as a teacher at our Department of Translation Studies in Prague. We have had a graduate who did very well in the video translation or localization industry. At one point, a year after graduation or so, he came back to see us and he simply said I'm done doing so well I would like to give back something to the faculty, something to the Department. It turned out that he really appreciated what he learned, and he really did well in his professional career, and he also felt an urge to give something back from what he gained. This was a success story; this was very encouraging feedback from this graduate. I would say for people who like this area, this is certainly an option to follow. The question is, how big is the market? I think this varies country to country, language to language. But from a professional point of view, and a linguistic point of view as well, the video game industry and localizing area is interesting, because you're facing specific challenges posed by the technology itself. For example, grammatical challenges, because in English for example you can call a female avatar and a male avatar the same thing, which does not work in Czech. So, if the player chooses this or that feature it cannot have one translation option, you have to have two translation paths for a female avatar or a male avatar or try to find some solutions that would overcome this challenge.

DDL: So, it poses new challenges to translators, yeah?

TS: Definitely.

Tomáš SVOBODA

Technology is indispensable. This is true both for non-literary and for literary translators increasingly
CLINA

vol. 7-1, June 2021, 25-31

elSSN: 2444-1961

Ediciones Universidad de Salamanca - CC BY-NC-ND 
DDL: OK. You've mentioned localization and, here at the faculty, sometimes we hear that it is one of the main tasks that translators have to undertake. We would like to know what localization is exactly.

TS: The concept has evolved from the meaning that it used to have. The original meaning was actually to cater for culturally bound expressions in original text that you're translating.

There are some things that don't occur in your culture and the translators have to cater for those specific features in the original and have to transpose those features in the translation. This is the original notion of localization. Over time this changed, and when we are using the term «localization» today, we refer to other ideas. Sometimes for me it seems that simply calling a translator's activity «translating» might sound a bit too simplistic for some audiences. Many people think that everybody who knows a foreign language can translate easily, which is not true. If you want to be a professional, you really have to know what you're doing. But for some reason translating as an activity has become a rather simplistic word. This might have prompted people to start using a different term for what the translators do, and they started to think of localizing, localization. I think that localization is actually a well performed translation. If you consider catering for the cultural differences between cultures, this is what a good translator needs to do on everyday basis. Taking into account the channel, through which the content is communicated, this is what a good translator does on an everyday basis as well. So, localization as such is not so far removed from good translation.

Obviously, localization means today localizing video games or websites, programs, etc. I would say, it is translation that needs to take into account all those extra features, but it's not very different from good translation.

DDL: Thank you very much for this definition. This brings us to the last question. We have many more topics that we would like to talk about with you, but lastly, we would like to know, as far as technological skills are concerned, this technological skill which we have just discussed: will translators in the future, those who are finishing their studies right now, be expected to have a higher degree of familiarity with these technologies?

TS: Yes. Technology is indispensable. This is true both for non-literary translators and for literary translators increasingly. We have become familiar with all those terms and notions, such as CAT tools, machine translation, post-editing machine translation, workflow, automation or semi-automation, terminology management, project management. All those concepts and notions. This is what a graduate really needs to have packed in their backpack when leaving the faculty, what he or she needs to be aware of and familiar with when they want to be compatible with the market requirements. So, I tell my students with regards to the technology requirements of today, «please, see it as a new opportunity, it gives you new opportunities to boost your productivity and work with the language in a new way, it's not a threat it's a new avenue, a new option». And

Tomáš SVOBODA Technology is indispensable. This is true both for non-literary and for literary translators increasingly
CLINA

vol. 7-1, June 2021, 25-31

elSSN: 2444-1961

Ediciones Universidad de Salamanca - CC BY-NC-ND 
I call technology in translation a kind of a new language, a new language skill that you need to learn apart from your working languages. Technology is also something that you should be familiar with and that you should be friends with.

DDL: Thank you very much Tomaš Svoboda. You've provided very interesting insights into this topic and we're very thankful for having had you here today.

TS: Thank you very much for having me!

\author{
Entrevista: «Don de Lenguas» \\ Transcripción: Beatriz Guerrero García \\ Revisión: Maria Ward, Universidad Glasgow \\ Enlace: https://www.ivoox.com/entrevista-a-toma-svoboda-audios-mp3_rf_48605526_1.html \\ Duración: 20:12:00
}

\title{
NOTA BIOGRÁFICA
}

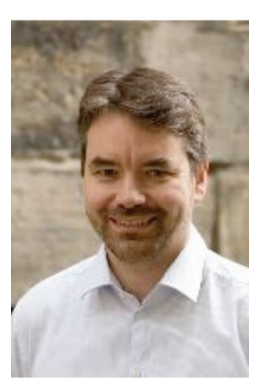

Tomáš Svoboda is Head of the German Department at the Institute of Translation Studies, Charles University, Prague, Czech Republic and coordinator of a double-degree study program with Leipzig University, Germany. After graduating with a degree in English and German translation from the Institute, Tomáš earned his PhD in Translation Studies there in 2004. From 2004 to 2007 Tomáš worked as an inhouse translator and training coordinator for the Czech Language Department of DGT EC in Luxembourg, and subsequently for four years as a contractor for the European Central Bank in Frankfurt, Germany. He is an active translator and auditor under the ISO 17100 standard. Tomáš is a member of the Board of the EMT network and a member of the Executive Board of the Czech Translators and Interpreters Union. His research interests involve Institutional Translation Studies, tools and technologies in translation, translator training, translation quality, translation history, the future of the translation profession.

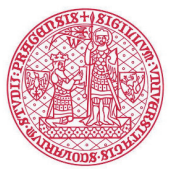

Tomáš Svoboda:

https://orcid.org/0000-0003-2734-4746

Tomáš SVOBODA

Technology is indispensable. This is true both for non-literary and for literary translators increasingly 


\section{BIBLIOGRAFÍA}

Svoboda, Tomáš. 2019. Překlad jako rozhodovací proces: rozpracování konceptu J. Levého a aplikace tohoto prístupu na institucionální překlad. Acta Universitatis Carolinae. Philologica 4. Praha: Univerzita Karlova - Nakladatelství Karolinum, 2019, pp. 11-33. ISSN 0567-8269. https://doi.org/10.14712/24646830.2020.2

Svoboda, Tomáš (ed.). 2019. Překlady pro EU [Translating for the EU]. Praha: Nakladatelství Milada Karez, 2019. https://utrl.ff.cuni.cz/UTRLFF-415-version1-preklady_pro_eu_svoboda_tomas_et_al_2019.pdf

Rothwell, Andrew and Tomáš Svoboda. 2019. Tracking Translator Training in Tools and Technologies: Findings of the EMT Survey 2017. Journal of Specialised Translation. 32, 2019. ISSN 1740-357X. https://www.jostrans.org/issue32/art_rothwell.pdf

Svoboda, Tomáš. 2019. Computing and Translation: An Overview for Technical Communicators. In: Maylath, Bruce, Kirk St.Amant (eds.) Translation and Localization. A Guide for Technical and Professional Communicators. 1st Edition. New York: Routledge, 2019. https://www. routledge.com/Translation-and-Localization-A-Guide-for-Professional-and-Technical-Communicators/Maylath-StAmant/p/book/9781138319943.

Svoboda, Tomáš. 2018. Hermeneutické čtení děl Jiřího Levého [Hermeneutic Reading of the Works of Jiř́ Levý]. Acta Universitatis Carolinae. Philologica. Translatologica Pragensia. Praha: Univerzita Karlova - Nakladatelství Karolinum, 2018, pp. 21-41. ISSN 0567-8269. https://doi.org/10.14712/24646830.2018.13

Tomáš SVOBODA Technology is indispensable. This is true both for non-literary and for literary translators increasingly 